\title{
Towards malaria elimination - a new thematic series
}

Marcel Tanner ${ }^{1 *}$, Marcel Hommel ${ }^{2}$

\begin{abstract}
The launch of a new thematic series of Malaria Journal - "Towards malaria elimination" - creates the forum that allows carrying scientific evidence on how to achieve malaria elimination in specific endemic settings and conditions into the circles of scientists, public health specialists, national and global programme managers, funders and decision makers.
\end{abstract}

The paradigm shift from malaria control to malaria eradication following declarations at the Gates Malaria Forum in October 2007 [1,2] and subsequent support voiced by World Health Organization (WHO) [2], the Board of the Roll Back Malaria (RBM) Partnership and many other institutions has renewed inspiration for innovation and public health action. New initiatives such as attempts to eliminate malaria in the Southern African region [3] and Pacific Island states [4] and the new global agenda and field manual for malaria elimination from WHO's Global Malaria Programme $[5,6]$ foreshadowed this movement and are preparing the ground for another global attempt at eradication. Very swiftly a coherent global action plan for malaria eradication was established and approved by RBM in late 2008 [7]. A group of scientists, public health decision makers, control programme managers and funders, the Malaria Elimination Group, compiled - based on all currently available scientific evidence and case studies - a guide to policy makers for malaria elimination for areas that embark or have embarked on elimination strategies [8]. All these recent efforts illuminate a pathway from control through to elimination and, eventually to eradication, as the only ethical long-term strategy.

Alongside and interrelated with these important developments over the past decade, a remarkable decline of malaria incidence in several countries in sub-Saharan Africa, and world-wide, has been observed in recent years. This fall seems to have started before the widespread introduction of insecticide-treated nets and is a

* Correspondence: marcel.tanner@unibas.ch

'Guest Editor 'Towards Malaria Elimination' reflection of the renewed efforts in malaria control [9-15]. In the world today, 108 countries are malariafree and the remaining one hundred countries still experience malaria transmission; 39 of these countries have already embarked on elimination while the remaining 61 countries implement control strategies [8].

It is against this background that the malaria community has to prepare for an "elimination/eradication era". The challenges remain formidable, but efforts must focus at all levels from developing better tools to how existing and future tools can be strategically combined for maximum synergistic effectiveness when integrated into different health and social systems prevailing in endemic areas. Any effort towards elimination - and here again one can learn from the past - needs to be (i) a synchronous global effort, locally adapted in all endemic areas, (ii) sustained over the long-term and - equally important - (iii) continuously strengthened by more basic and applied research.

Although Malaria Journal has already, over the past few years, published many important papers related to malaria control, it was felt that a specific, on-going, thematic series on elimination would further stimulate the debate. "Towards malaria elimination" offers the first and continuous, scientific platform on elimination and eradication. It is aimed at exchanging, discussing and developing evidence, innovation and concrete experience from all areas and levels.

For its launch, the thematic series includes two papers, one describing the assessment of parasite burden in Sri Lanka [16], the other one describing an integrated programme to eliminate malaria from the island of Principe [17].

(c) 2010 Tanner and Hommel; licensee BioMed Central Ltd. This is an Open Access article distributed under the terms of the Creative 
“Towards malaria elimination" welcomes original papers, reviews, commentaries and opinion pieces on malaria elimination and eradication, and hopes that this mix of scientific information and debate will catalyze and dynamize the move towards more intensified control and progressively malaria elimination within a spirit of mutual learning for change. The Editors very much hope that many scientists, public health professionals and policy makers will start using "Towards malaria elimination" as one of their ways to share new evidence or to discuss evidence presented in the scientific literature.

\section{Author details}

'Guest Editor 'Towards Malaria Elimination'. 'Editor-in-chief, Malaria Journal.

Received: 31 December 2009

Accepted: 20 January 2010 Published: 20 January 2010

\section{References}

1. Bill and Melinda Gates Foundation: Bill and Melinda Gates Foundation Malaria Forum - Day-2 Transcript 2007

2. Roberts L, Enserink M: Did they really say...eradication?. Science 2007, 318:153-154.

3. Southern African Development Community (SADC): Strategic plan to fight against malaria in the region SADC Ministers of Health 2007.

4. Australian Government Overseas Aid Programme: Commitment to malaria control in Solomon Islands and Vanuatu 2007.

5. Delacollette C, Rietveld A: WHO GMP-Informal consultation on malaria elimination: setting up the WHO agenda World Health Organization, Tunis 2006.

6. WHO Global Malaria Programme: Malaria elimination: a field manual for low and moderate endemic countries WHO Geneva 2007, 85.

7. Roll Back Malaria Partnership: A Global Malaria Action Plan Geneva: World Health Organization 2008.

8. Feachem RGA and the Malaria Elimination Group: Shrinking the malaria map: a guide on malaria elimination for policy makers San Francisco: The Global Health Group, Global Health Sciences, University of California, San Francisco 2009.

9. Guerra CA, Gikandi PW, Tatem AJ, Noor AM, Smith DL, Hay SI, Snow RW: The limits and intensity of Plasmodium falciparum transmission: implications for malaria control and elimination worldwide. PLoS Med 2008, 5:e38.

10. Okiro E, Hay SI, Gikandi PW, Sharif SK, Noor A, Peshu N, Marsh K, Snow RW: The decline in pediatric malaria admissions on the coast of Kenya. Malar J 2007, 6:151.

11. Schellenberg D, Menendez C, Aponte J, Guinovart C, Mshinda H, Tanner M, Alonso P: The changing epidemiology of malaria in Ifakara Town, Southern Tanzania. Trop Med Int Health 2004, 9:68-76.

12. Bhattarai A, Ali AS, Kachur P, Martensson A, Abbas AK, Khatib R, Almafazy A, Ramsan M, Rotllant G, Gerstenmaier JF, Molteni F, Abdulla S, Montgomery SM, Kaneko A, Bjorkman A: Impact of artemesinin-based combination therapy and insecticide- treated nets on malaria burden in Zanzibar. Plos Medicine 2007, 4:e309.

13. Sharp B, Kleinschmidt I, Streat E, Maharaj R, Barnes K, Durrheim DN, Ridl FC, Morris N, Seocharan I, Kunene S, La Grange JJP, Mthembu JD, Maartens F, Martin CL, Barreto A: Seven years of regional malaria control collaboration- Mozambique, South Africa and Swaziland. Am J Trop Med Hyg 2007, 76:42-47.

14. Rodrigues A, Armstrong Schellenberg J, Kofoed PE, Aaby P, Greenwood B: Changing pattern of malaria in Bissau, Guinea Bissau. Trop Med Int Health 2008, 13:410-417.

15. Nyarango PM, Gebremeskel T, Mebrahtu G, Mufunda J, Abdulmumini U, Ogbamariam A, Kosia A, Gebremichael A, Gunawardena D, Ghebrat Y, Okbaldet $Y$ : A steep decline of malaria morbidity and mortality trends in
Eritrea between 2000 and 2004: the effect of combination of control methods. Malar J 2006, 5:33.

16. Rajakaruna RS, Alifrangis M, Amerasinghe PH, Konradsen F: Pre-elimination stage of malaria in Sri Lanka: assessing the level of hidden parasites in the population. Malar J 2009.

17. Lee PW, Liu CT, Rampao HS, do Rosario VE, Shaio MF: Pre-elimination of malaria on the island of Principe. Malar J 2009.

doi:10.1186/1475-2875-9-24

Cite this article as: Tanner and Hommel: Towards malaria elimination - a new thematic series. Malaria Journal 2010 9:24.
Publish with BioMed Central and every scientist can read your work free of charge

"BioMed Central will be the most significant development for disseminating the results of biomedical research in our lifetime. "

Sir Paul Nurse, Cancer Research UK

Your research papers will be:

- available free of charge to the entire biomedical community

- peer reviewed and published immediately upon acceptance

- cited in PubMed and archived on PubMed Central

- yours - you keep the copyright
BioMedcentral 